\title{
Полиморфизм популяций Anemone jenisseensis (Korsh.) Holub (Ranunculaceae) в Южной Сибири
}

\section{Polymorphism of Anemone jenisseensis (Korsh.) Holub (Ranunculaceae) populations in Southern Siberia}

\author{
Мариничева А. Н., Ямских И. Е. \\ Marinicheva A. N., Yamskikh I. E. \\ Сибирский федеральный университет, г. Красноярск, Россия. E-mail: alexandra.marinicheva@outlook.com \\ Siberian Federal University, Krasnoyarsk, Russia
}

\begin{abstract}
Peфepam. Проведен морфолого-генетический анализ 10 популяций Anemone jenisseensis, произрастающих в южной части Красноярского края. Выявлено, что популяции, произрастающие в сообществах Западного Саяна, характеризуются наибольшими размерами вегетативных органов, высокими показателями семенной продуктивности и максимальным генетическим разнообразием. Установлено, что изученные популяции нормальные, с преобладанием особей виргинильных и генеративных возрастных состояний. При проведении кластерного анализа на основании данных ISSR-PCR анализа обнаружено, что наибольшим сходством обладают популяции, произрастающие в географически близких местообитаниях. По морфологическим признакам такого разделения не выявлено.
\end{abstract}

Ключевые слова. Морфолого-генетический анализ, популяция, Южная Сибирь, ISSR-PCR, Anemone jenisseensis.

Summary. Ten Anemone jenisseensis populations growing in the southern part of the Krasnoyarsk region were studied by morphological and genetic analyses. Populations from the West Sayan Mountains are characterized by the largest sizes of the vegetative organs, high rates of seed production and the maximum genetic diversity. Studied populations are normal with prevalence of virginile and generative age groups. Cluster analysis of ISSR-PCR data revealed the largest similarity for geographically close habitats. Cluster analysis of morphological features hadn't revealed same tendency.

Key words. Anemone jenisseensis, ISSR-PCR, morphological and genetic analyses, population, Southern Siberia.

Одной из наиболее интересных и относительно слабо изученных в Южной Сибири является группа весенних эфемероидов, принадлежащих к роду Апетопе. Объектом нашего исследования является A. jenisseensis (Korsh.) Holub - сибирский эндемик, занесенный в «Красную книгу Иркутской области» (2010). Вид распространен в пределах Красноярского края, Хакасии. Встречается в лесах Томской, Кемеровской, Иркутской областей. К настоящему времени отсутствуют данные о морфологической и генетической структуре популяций ветреницы енисейской.

Цель исследований - изучение модификационной и генетической изменчивости природных популяций $A$. jenisseensis.

Сбор материала проводился в период с 2007 по 2018 гг. Объектом исследований явились популяции A. jenisseensis, произрастающие в следующих местообитаниях. Западный Саян: Ај1 сосняк орляково-разнотравный (окр. пос. Майна, долина р. Уй); Аj2 - березово-сосновый лес орляковоразнотравно-злаковый (окр. с. Ермаковского); Ај3 - березово-сосновый лес хвощево-разнотравный (окр. д. Григорьевка); Aj4* - вырубка сосняка со следами пожара (Осиновские косогоры); Aj5 - пойменный ивняк широкотравно-страусниковый (окр. пос. Танзыбей); Аj6 - березово-сосновый лес папоротниковоширокотравный (хр. Осиновский); Ај7 - березняк с елью разнотравно-осочковый (пойма р. Иджим); Восточный Саян: Ај8 - осиново-березновый лес крупнотравно-папоротниовый (окр. г. Красноярска, пойма р. Лалетино); Красноярская лесостепь: Ај9 - березово-осиновый лес разнотравно-орляковый (Николаевская сопка); Ај10* - вырубка под ЛЭП, луг высокотравно-злаковый (станция Рябинино). 
При изучении состояния популяций A. jenisseensis определяли возрастной состав, плотность побегов, проективное покрытие, оценивали изменчивость вегетативных и генеративных признаков, семенную продуктивность (Работнов, 1950; Дюрягина, Иванова, 1985), изучали генетическую вариабельность на основе ISSR-PCR анализа. Статистическая обработка морфологических и генетических данных произведена в программах Statistica 7.0, Popgene version 1.32 и TFPGA version 1.3 (Miller, 1997).

Наибольшая плотность $A$. jenisseensis зафиксирована для популяции, произрастающей в окрестностях г. Красноярска (Ај9 - 30,7 шт./м²). Минимальное число побегов было отмечено для вырубки под ЛЭП $\left(\mathrm{Aj} 10^{*}, 14,6\right.$ шт./ $\left.\mathrm{M}^{2}\right)$ и в березово-сосновом лесу орляково-разнотравно-злаковом в окрестностях с. Ермаковского, Западный Саян (Аj2, 15 шт./м²).

В ходе изучения возрастного состава популяций $A$. jenisseensis выявлено, что все изученные популяции нормальные, неполночленные. Отсутствие особей сенильного возрастного состояния согласуется с данными других авторов (Барыкина и др., 1986; Барыкина, Потапова, 1994) и объясняется постоянным возобновлением подземных органов и значительным вегетативным потенциалом растений. Базовый онтогенетический спектр - левосторонний с хорошо выраженным пиком, приходящимся на взрослый виргинильный период (39,04-46,67 \%). Для популяций, произрастающих в окрестностях г. Красноярска (Ај8 и Ај9), отмечено преобладание особей генеративного возрастного состояния $(35,2-$ $37,8 \%)$.

При анализе среднепопуляционных значений признаков A. jenisseensis выявлено, что наибольшими размерами осевых органов характеризуются особи, произрастающие в сосновых сообществах Западного Саяна (Aj1, Aj2, Aj3). Максимальные размеры листьев зафиксированы для западносаянских популяций Aj3 и Aj5, а также для красноярской Aj9. Минимальные показатели всех вегетативных признаков характерны для растений ветреницы енисейской, произрастающих в окрестностях г. Красноярска на вырубке под ЛЭП (Ај10*).

Максимальные показатели реальной семенной продуктивности A. jenisseensis отмечены для западносаянской популяции Аj5 (пойменный ивняк широкотравно-страусниковый), где количество завязавшихся плодов составляет 27,4 шт., а коэффициент семенификации - 74,6 \%. Для популяции Ај10*, произрастающей на вырубке под ЛЭП, сравнительно низкие значения морфологических параметров сочетаются с высокими показателями семенной продуктивности, численности и средним уровнем внутрипопуляционной изменчивости, что свидетельствует об относительно стабильных условиях.

Генетический полиморфизм ветреницы енисейской изучен на примере популяций, произрастающих в лесах Западного Саяна (Aj1, Aj3, Aj5-Aj7), Восточного Саяна (Ај8) и Красноярской лесостепи (Ај9). В ходе анализа выявлено 160 фрагментов ДНК, процент полиморфизма которых суммарно составляет 97,5. Число амплифицированных фрагментов ДНК, в зависимости от праймера (табл.), варьировало от 14 (НВ8) до 33 (17899B). Число полиморфных фрагментов в суммарной выборке изменялось от 63 до 98.

Таблица

Характеристика праймеров, использованных в ISSR-PCR анализе

\begin{tabular}{|c|c|c|c|}
\hline Название & $\begin{array}{c}\text { Последовательность } \\
\left(5^{\prime}->3^{\prime}\right)\end{array}$ & $\begin{array}{c}\text { Количество } \\
\text { амплифицированных } \\
\text { фрагментов }\end{array}$ & $\begin{array}{c}\text { Количество } \\
\text { полиморфных фрагментов }\end{array}$ \\
\hline $844 \mathrm{~B}$ & $(\mathrm{CT})_{8} \mathrm{GC}$ & 32 & $32(100 \%)$ \\
\hline $17898 \mathrm{~A}$ & $(\mathrm{CA})_{6} \mathrm{AC}$ & 29 & $27(93,11 \%)$ \\
\hline $17898 \mathrm{~B}$ & $(\mathrm{CA})_{6} \mathrm{GT}$ & 26 & $25(96,15 \%)$ \\
\hline $17899 \mathrm{~B}$ & $(\mathrm{CA})_{6} \mathrm{GG}$ & 33 & $32(96,97 \%)$ \\
\hline $\mathrm{HB} 8$ & $(\mathrm{GA}) 6 \mathrm{GG}$ & 14 & $13(92,86 \%)$ \\
\hline $\mathrm{HB} 12$ & $(\mathrm{CAC}) 3 \mathrm{GC}$ & 26 & $26(100 \%)$ \\
\hline
\end{tabular}

Максимальный уровень полиморфизма ДНК A. jenisseensis зафиксирован при использовании праймеров 844B и НB12 (по 100 \%). Уровень генетического разнообразия в популяциях варьирует 
от 39,38 до 61,25 \% и имеет максимальные показатели в западносаянской $\mathrm{Aj} 1$ (P=61,25 \% $\mathrm{H}_{\mathrm{e}}=0,202$ $\left.\mathrm{I}_{\mathrm{o}}=0,308\right)$. Также высокие показатели генетической изменчивости отмечены для низкогорных западносаянских популяций $\mathrm{Aj} 5\left(\mathrm{P}=58,12 \% \mathrm{H}_{\mathrm{e}}=0,202 \mathrm{I}_{\mathrm{o}}=0,305\right)$ и $\mathrm{Aj} 7\left(\mathrm{P}=58,12 \% \mathrm{H}_{\mathrm{e}}=0,199 \mathrm{I}=0,301\right)$. Минимальные значения генетического разнообразия зафиксированы для популяции Аj6, произрастающей в Западном Саяне $\left(\mathrm{P}=39,38 \% \mathrm{H}_{\mathrm{e}}=0,136 \mathrm{I}=0,206\right)$.

На дендрограммах сходства, построенных на основе морфологических и генетических данных, мы видим несколько различающуюся картину (рис.). Генетический анализ показывает разделение по географическому принципу: с высокой степенью достоверности отдельные кластеры формируют саянские (Aj3, Aj5 и Aj7) и красноярские (Aj8, Aj9) популяции. На дендрограмме сходства по морфологическим признакам, построенной с помощью кластерного анализа (метод Уорда), четкой картины разделения по географическому и фитоценотическому принципу не наблюдается. Сходством обладают красноярские популяции (Ај8 и Ај9) и примкнувшая к ним Ај1. Два отдельных кластера формируют саянские популяции. Также отмечается морфологическое сходство красноярской $\left(\mathrm{Aj} 4^{*}\right)$ и саянской $\left(\mathrm{Aj} 10^{*}\right)$ популяций, произрастающих в нарушенных сообществах.

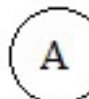

Linkage Distance

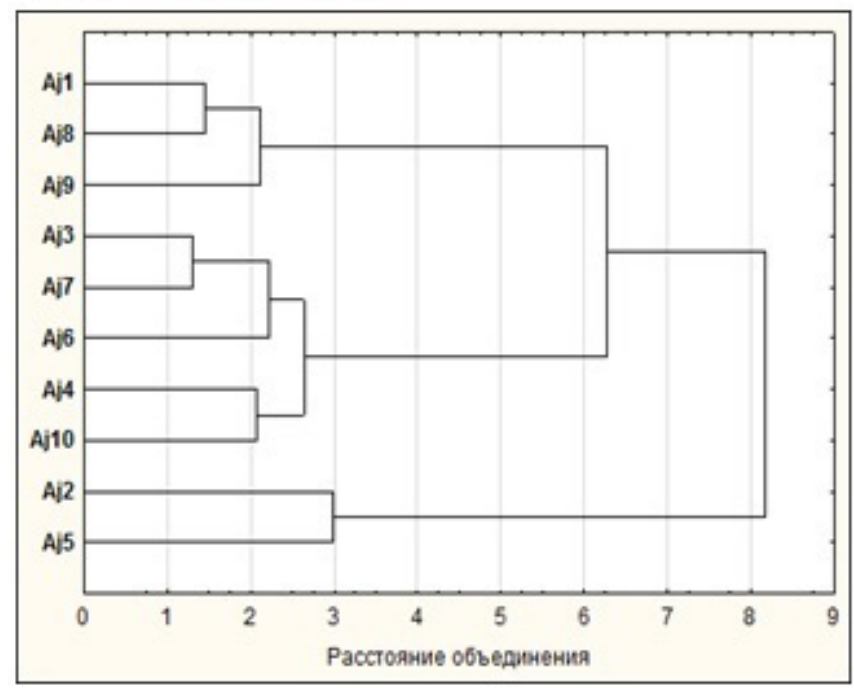

Б

Coancestry distance (Reynolds et al. 1983)

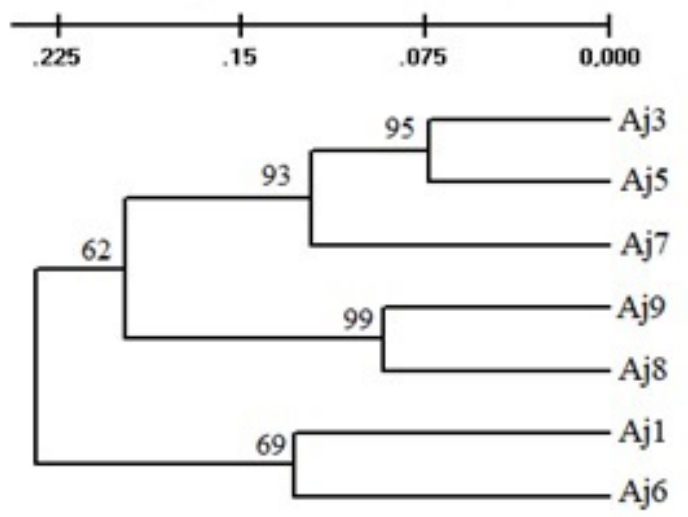

Рис. Дендрограммы сходства популяций Anemone jenisseensis на основе данных морфологического (A) ISSR-PCR анализов (Б).

Таким образом выявлено, что популяции, произрастающие в сообществах Западного Саяна, характеризуются наибольшими размерами вегетативных органов, высокими показателями семенной продуктивности и максимальным генетическим разнообразием. Установлено, что изученные популяции нормальные, с преобладанием особей виргинильного и генеративного возрастных состояний. При проведении кластерного анализа на основании генетических данных обнаружено, что наибольшим сходством обладают популяции, обитающие в географически близких местообитаниях. По морфологическим признакам такого разделения не выявлено.

\section{ЛИТЕРАТУРА}

Барыкина Р. П., Потапова Н. Ф., Степанов Б. П. Морфогенез побегов некоторых лесных эфемероидов рода Anemone L. // Биологические науки, 1986. - № 7. - С. 86-92.

Барыкина Р. П., Потапова Н. Ф. Биоморфологический анализ видов рода Anетопе L. флоры бывшего СССР в ходе онтогенеза // Бюл. МОИП. Отд. биол., 1994. - Т. 99, вып. 5. - С. 124 - 137.

Дюрягина Г. П., Иванова М. М. Характеристика ценопопуляций редких видов флоры Бурятии // Бот. журн., 1985. - Т. 70, №11. - C. 1529-1538. 
Красная книга Иркутской области / гл. ред. О. Ю. Гайкова, отв. ред. В. В. Попов. - Иркутск: Время странствий, 2010. -478 с.

Работнов T. A. Жизненный цикл многолетних травянистых растений в луговых ценозах // Геоботаника. - М.; Л.: Изд-во АН СССР, 1950. - Т. 4. - С. 70- 